\title{
Affirmative action and equity in Aboriginal and Torres Strait Islander health
}

\section{THE SECOND OF THREE FINALISTS' ESSAYS}

A s Indigenous Australians, our health lags behind that of indigenous groups in other settler colonial nations such as the United States, Canada and New Zealand. ${ }^{1}$ Similarly, we are far behind these nations in relation to Indigenous participation in the health workforce and the professions generally. A compelling illustration of this is the fact that the first indigenous doctors in North America and New Zealand graduated in 1889 and 1899, respectively, while the first Indigenous doctor in Australia graduated almost a century later, in 1984. ${ }^{2,3}$

It is undeniable that our poor health and our low participation in the health workforce are related. Increasing recognition of this has led to a situation in which there are now over 80 qualified Indigenous doctors and almost 100 Indigenous medical students in Australia. ${ }^{4}$ This achievement has only been possible because we live in the era of "self-determination" that was born, as was I, during the 1970s. I am a multiracial Australian, with Aboriginal, Anglo and Asian ancestry. Because my grandmother (being my only Indigenous ancestor) was a member of the "stolen generations", and because I am fair-skinned, I started life with an ambivalent Indigenous identity which has been profoundly shaped by the policies of affirmative action (or positive discrimination) that epitomise the era of self-determination.

My first experiences with affirmative action occurred in high school, when I was showcased as a role model for other Indigenous students. I went on to gain a degree in science and start a career in health research through an Indigenous cadetship. Affirmative action also provided me with the financial means to complete a Master of Medical Statistics - the first Indigenous Australian to do so - and with preferential access to scholarships, which allowed me to complete a Master of Public Health and to undertake a $\mathrm{PhD}$. In return for this assistance, I have spoken at Indigenous youth summits and school career days, tutored, taught, and donated prize money to Indigenous tertiary students, and conducted research and teaching in Indigenous health on topics of importance to Indigenous people (such as the health effects of racism). ${ }^{5}$ In addition, I have brought an "Indigenous" perspective to a range of committees, forums, round tables, community groups, conferences, colleagues and students.

These experiences are in keeping with the goals of affirmative action, which are to create equality of opportunity and outcome for Indigenous Australians and, for the benefit of all Australians, to promote diversity through equitable representation of Indigenous people in society. Affirmative action is achieved, in practice, by assisting individual Indigenous people to become more "successful". In addition, there is often an implicit assumption that the Indigenous recipients of affirmative action will themselves strive to reduce social inequities, promote opportunities for and enhance representation of Indigenous people, and act as role models.

While medicine has made some progress towards these goals, and the role played by Aboriginal and Torres Strait Islander health workers has been crucial, other areas of health have not fared as well. There has been little government support for increasing the number of Indigenous nurses or allied health professionals, ${ }^{2}$ with the notable exception of the recent Puggy Hunter Memorial Scholarships. ${ }^{6}$ Health research is a particularly lonely field. I knew of no other Indigenous person studying at my institution in the same degree program as me. Also, milestones such as the first Indigenous doctor and the first Indigenous clinical psychologist to gain a PhD have only been achieved in the 21 st century.

Clearly, there is still considerable scope for applying affirmative action in health and other sectors in which Indigenous people continue to suffer from disadvantage. However, I believe there are complexities inherent in both the aims and practice of affirmative action that need to be considered in order to improve social outcomes for Indigenous Australians and allow our diversity to contribute to Australia's future. In this essay, I will share with you what I have learnt about the benefits and pitfalls of affirmative action as an Indigenous health professional during the past decade.

The most obvious difficulty faced by Indigenous people who are beneficiaries of affirmative action is the self-doubt stemming from accusations that we do not merit such support. Unfortunately, it appears that many Australians still think Indigenous people get "too many benefits". In one survey, almost a third of participants believed that car loans are paid for us by the government, and almost two-thirds thought that we receive more social security benefits than non-Indigenous people. ${ }^{7}$ In another survey, more than half of respondents believed Indigenous people were "treated over generously by the government". "The hostility to affirmative action programs, which is compounded by these misconceptions, can only be reduced through education that explains the benefits of diversity and the need to remedy historical injustice. ${ }^{9}$

There is also an urgent and profound need to tackle systemic racism in Australia, which, in its most extreme form, led to the death of Private Damien Palmer. After entering the army through an affirmative action policy, he committed suicide following racist taunts and intense ridicule from fellow soldiers and instructors. ${ }^{10}$ Systemic racism is something that white Australians, as those who benefit most from the system of racial oppression, are in the best position to combat. Indigenous people, in contrast, face anguish and rapid "burnout" when leading the fight against this insidious form of racism.

The intense doubt of our self-worth which some Indigenous people experience as a result of affirmative action can be reduced by ensuring that Indigenous people are only placed in positions and given training or learning opportunities for which they have the appropriate commitment, skills, abilities and qualifications. If we cannot do a job or don't have the capacity to benefit from a program, this is no doubt due to a legacy of oppression and colonisation. However, this situation is not remedied by the tokenism being engaged in by far too many organisations around Australia. Not only are those caught up in tokenism unable to effectively advance the goals of affirmative action, but they are also being set up to fail or, worse, set up as ever more prominent "tokens", whose increasing visibility as such severely hampers ongoing efforts to redress Indigenous disadvantage. 
It is clear that affirmative action, no matter which segment of the Indigenous population is targeted, is most helpful to those who are most advantaged to begin with. ${ }^{11}$ It is easiest, and perhaps most appropriate, for those who have the most capacity to benefit to take up whatever opportunities are on offer. However, there is still a tendency for both Indigenous and non-Indigenous people to assume that being Indigenous is synonymous with a certain "marginality or victimage". 12,13 This misconception can leave Indigenous recipients of affirmative action not only doubting their self-worth but also being seen as threatening "tall poppies" ${ }^{2}$ and having their Indigenous identity questioned. I have certainly been accused of taking positions that should have been given to "real blacks" who weren't as acculturated to white society as me and/or who had darker skin. These issues need to be brought into the open, so that Indigenous people who are beneficiaries of affirmative action can share these difficult experiences and learn from each other about effective coping strategies.

In implementing affirmative action policies, we need to stop simply seeing "Indigenous people" as a single entity and instead see individuals with multiple personal and professional identities, including Indigeneity. We need to believe in and respect Indigenous people as individuals who have their own goals, principles, flaws and foibles and who may or may not be interested in, capable of, or suitable for a specific affirmative action policy or program. Despite what is often assumed, some Indigenous people - just like some non-Indigenous people — are not effective role models or interested in working towards emancipatory goals. Therefore, it is vital to consider, in every case, whether, and to what degree, affirmative action is aimed at helping an individual become more successful, at increasing diversity, or at aiding recipients who will then contribute to the goals of affirmative action themselves.

These questions need to be addressed by all Australians and will require us to grapple with the historical baggage that accompanies the stereotyped Indigenous identity we have inherited as a nation. ${ }^{14}$ All of us need to truly come to terms with the diversity of Indigenous people in Australia, rather than just paying lip service to this notion. To do this, non-Indigenous Australians must overcome their reluctance to engage in debate about Indigenous affairs, ${ }^{15}$ and Indigenous Australians must stop acting as if dissenting views are nothing more than simplistic attacks on Indigenous people. ${ }^{2}$

If there is one thing that most people agree on, it is that there is no simple solution to the complex problems in Indigenous health. ${ }^{2}$ In relation to our history as a nation, the struggle to improve the lives of Indigenous people in Australia has only just begun and has a long way to go before equity is achieved. In the field of Indigenous health research, in which I work (and, I suggest, in many other fields), we require a greater clarity of purpose and increased patience in relation to affirmative action if we are to avoid jeopardising our efforts at improving the plight of Indigenous people.

Not all health research can involve Indigenous researchers, because those with sufficient training and experience are few and far between. We are not well served by setting up Indigenous people as "researchers" when they are not, or by prioritising affirmative action to such an extent that the very research we do is compromised. Let us hope that the spectacular rise in the number of Indigenous doctors continues until equity in medicine is reached and that we can match this achievement in Indigenous health research. In working towards these goals we need to recognise that the era of self-determination, like those before it, won't last forever. What could perhaps be called the "partnership era" may already be replacing it, as exemplified by policy approaches such as shared responsibility agreements. ${ }^{16}$ The role of affirmative action in this new era is not assured and will only be maintained by addressing the difficult issues now, so that Australia may one day become an inclusive nation where, as Indigenous people, we can maintain our unique identity while playing a full role in society and enjoying the same level of health as other Australians.

\section{Yin C Paradies \\ PhD Student, Menzies School of Health Research Charles Darwin University, Casuarina, NT and Centre for Health and Society, University of Melbourne yin.paradies@menzies.edu.au}

Competing interests: The author is funded by a National Health and Medical Research Council training scholarship for Indigenous health research, an NHMRC population health capacity-building grant and a Cooperative Research Centre for Aboriginal Health scholarship. These funding sources had no involvement in the authorship of the manuscript.

1 Paradies Y, Cunningham J. Placing Aboriginal and Torres Strait Islander mortality in an international context. Aust N Z J Public Health 2002; 26: 11-16.

2 Griew R, Sibthorpe B, Anderson I, et al. On our terms: the politics of Aboriginal health in Australia. In: Healy J, McKee M, editors. Accessing health care: responding to diversity. Oxford: Oxford University Press, 2004: 257-280.

3 Armstrong RM, Van Der Weyden MB. Indigenous health: tell us your story [editorial]. Med J Aust 2004; 180: 492.

4 Eldridge A. Doing us proud. Koori Mail 2004; 17 Nov: 25.

5 Aboriginal and Torres Strait Islander Research Agenda Working Group (RAWG) of the National Health and Medical Research Council. The NHMRC road map: a strategic framework for improving Aboriginal and Torres Strait Islander health through research. Canberra: Commonwealth of Australia, 2003.

6 Royal College of Nursing of Australia. Puggy Hunter Memorial Scholarship Scheme. Available at: http://www.rcna.org.au/pages/puggy.php (accessed Jul 2005)

7 Pedersen A, Griffiths B, Contos N, et al. Attitudes toward Aboriginal Australians in city and country settings. Aust Psychol 2000; 35: 109-117.

8 Dunn KM, McDonald A. The geography of racisms in NSW: a theoretical exploration and some preliminary findings from the mid 1990s. Aust Geog 2001; 32: 29-44.

9 Dovidio JF, Gaertner SL. Affirmative action, unintentional racial biases, and intergroup relations. J Soc Issues 1996; 52: 51-75.

10 Jones T. Racism rife in Army, mother says. Lateline, 12 Nov 2004 [ABC Online. TV program transcript]. Available at: http://www.abc.net.au/ lateline/content/2004/s1241701.htm (accessed Jul 2005).

11 Jones C. Maori-pakeha health disparities: can treaty settlements reverse the impacts of racism? Wellington, NZ: lan Axford Fellowships Office, 1999.

12 Morrissey P. Moving, remembering, singing our place. In: Grossman M, editor. Blacklines: contemporary critical writing by Indigenous Australians. Melbourne: Melbourne University Press, 2003: 189-193.

13 Kowal E, Paradies Y. Ambivalent helpers and unhealthy choices: public health practitioners' narratives of Indigenous ill-health. Soc Sci Med 2005; 60: 1347-1357.

14 Morrissey P. Aboriginality and corporatism. In: Grossman M, editor Blacklines: contemporary critical writing by Indigenous Australians. Melbourne: Melbourne University Press, 2003: 52-59.

15 Cowlishaw G. Racial positioning, privilege and public debate. In: Moreton-Robinson A, editor. Whitening race: essays in social and cultural criticism. Canberra: Aboriginal Studies Press, 2004: 59-74.

16 Collard KS, D'Antoine HA, Eggington DG, et al. "Mutual" obligation in Indigenous health: can shared responsibility agreements be truly mutual? Med J Aust 2005; 182: 502-504.

(Received 21 Jan 2005, accepted 13 Apr 2005) 